Naturalist in 1951 by Robert Lister. Lister had noted a pair without young in 1948 but accompanied by cygnets in 1949 and 1950. This is the only recond for the Cypress Hills given by Winston E. Blanko (1960. The Trumpeter Swan, its history, habits and population in the United Sitates. U.S. Fish and Wildlife Service.) It should be noted, of course, that Banko's study deals primarily with the United States population and' therefore only in a general way with Canada. A comparable study of the Trumpeter has been undertaken by the Canadian Wildlife Service, with investigations being conducted chiefly in British Columbia and Alberta by Ronald H. Mackiay, wildlife biologist.

EDITOR'S NOTE: A pair with one young seen October 4, 1960, by Mrs. Percy Drury on a small lake by the Cypress Hills Park, may have been the pair reported by Munro.

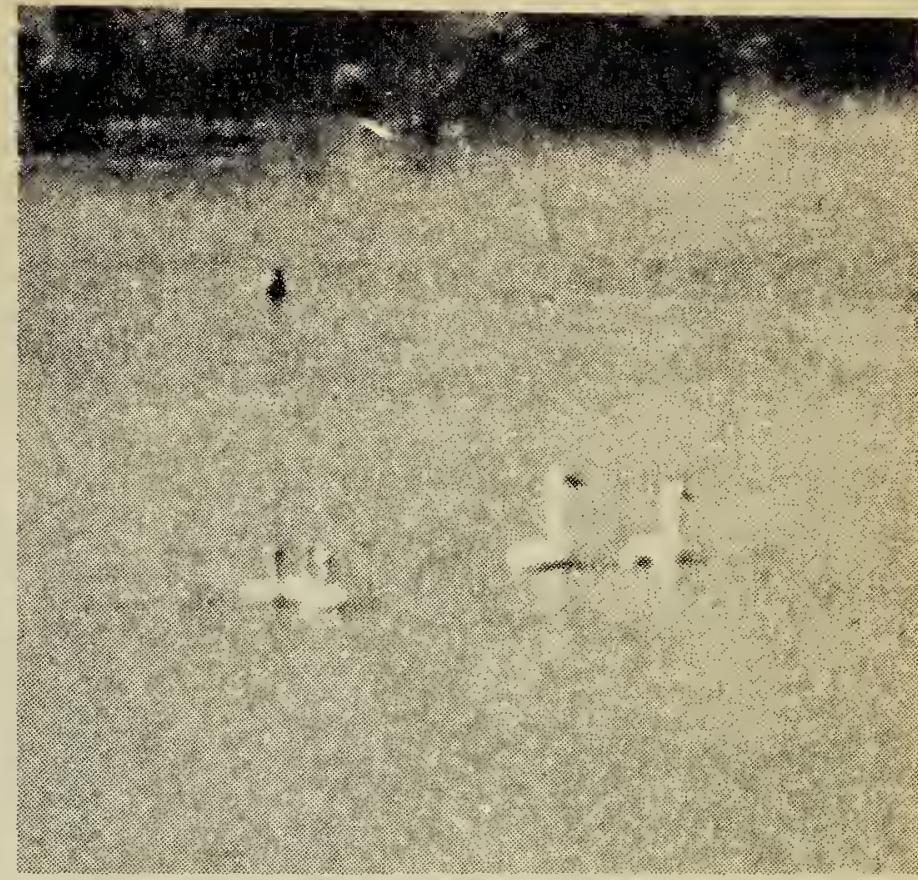

Photo by F. W. Lahrman. S.M.N.H. Trumpeter family on Adams Lake, August 18, 1960.

\title{
My Neighbours the Martins
}

\author{
by Elwin Baines, Tisdale
}

When Mr. and Mrs. E. W. Van Blaricom retired to Kelowna and I moved into their Tisdale home Mr. Van explained to me that the Martin house was included in the deal. However, no Purple.Martins had used the house up to that date, and they came to me in the following spring only because they found their former home in a neighbour's backyard occupied by a family of red squirrels. At the time Tree Swallows and House Sparrows were fighting for possession of my Martin house and the battle had reached a sitalemaite. At this opportune moment the Martins arrived to take over. Their tenantship of the house has not been i. doubt since, and they have raised broods in 1958, 1959 and 1960.

The Martins have proved themselves to be the most desirable neighbours. They chit chat over the clothes line on Monday mornings or they may have a few remarks for me when I drive up with the car or truck. They are extremely tidy and no refuse is ever seen around their house. Now that they are definitely settled nothing disturbs them, and half a dozen strangers can drop in unexpectedly without the Martins objecting.

I can now predict almost to the hour .when the Martins will return from the south each spring. For the past two years, Papa Martin has arrived here on May 8. For 10 days he appears alone and disconsolate. Then, promptly on May 18, Mama Martin is sitting on my telephone wire beside papa. They take possession immediately but do not lay eggs until well into June. Both birds carry in green leaves as soon as eggs are laid. Young hatch early in July. Both parents carry insects, small at first but as soon as the young develop many of those large blue dragonflies are eaten whole, wings and all.

The young do not take practice flights but fly like mature birds the first time out. They only return to the Martin house once or twice and leave the site almosit at once. It appears that Martins take more than one year to develop as there are always some immature birds around that look like last year's young.

What man could duplicate the feat of the Martins? Flying alone with nothing but a pair of strong wings and an unerring instinct the Martins set out from their southern retreat and land at a little white house on the eastern edge of Tisdale almosit to the hour each year. 